\title{
Influence of the extraction process on the antioxidant capacity of pequi pulp extracts
}

\author{
Influência do processo de extração na capacidade antioxidante de extratos de polpa de pequi \\ Influencia del proceso de extracción en la capacidad antioxidante de los extractos de pulpa de pequi
}

Received: 09/15/2021 | Reviewed: 09/22/2021 | Accept: 09/27/2021| Published: 09/28/2021

Flávia de Abreu Pinheiro
ORCID: https://orcid.org/0000-0002-4310-0592
Federal Institute of Espírito Santo, Brazil
E-mail: flavia.pinheiro@ifes.edu.br
Leonardo Luiz Okumura
ORCID: https://orcid.org/0000-0002-3056-2966
Federal University of Viçosa, Brazil
E-mail: leo.okumura@ ufv.br
Astréa Filomena de Souza Silva
ORCID: https://orcid.org/0000-0003-1992-7968
Federal University of Viçosa, Brazil
E-mail: astrea@ @ufv.br
Júnio Gonçalves da Silva
ORCID: https://orcid.org/0000-0002-3714-3633
Federal University of Minas Gerais, Brazil
E-mail: junio.ufv@ gmail.com
Deusélio Bassini Fioresi
ORCID: https://orcid.org/0000-0002-0912-0813
Federal Institute of Espírito Santo, Brazil
E-mail: deuselio.fioresi@ifes.edu.br
Wilton Soares Cardoso
ORCID: https://orcid.org/0000-0001-8067-6921
Federal Institute of Espírito Santo, Brazil
E-mail: wilton.cardoso@ifes.edu.br
Letícia Rocha Ferreira
ORCID: https://orcid.org/0000-0003-0983-5584
Federal University of Viçosa, Brazil
E-mail: ferreiralr@outlook.com
Edimar Aparecida Filomeno Fontes
ORCID: https://orcid.org/0000-0002-4370-8805
Federal University of Viçosa, Brazil
E-mail: eaffontes@ ufv.br

\begin{abstract}
The effect of the extraction procedure on the antioxidant capacity of extracts of pequi pulp: aqueous (AQ), alcoholic (ALC) and acetomethyl (AM), obtained respectively by the solvents water, ethanol and methanol followed by acetone, was investigated. Antioxidant action was expressed by the antioxidant capacity coefficient $(\mathrm{K})$ obtained by the electrochemical test (DPV) at different $\mathrm{pH}$ values, and in trolox equivalent (TEAC), through DPV (pH 7.15) and ABTS and DPPH spectrophotometric assays. Total carotenoid and phenolic contents were also determined. Through Principal Components and Cluster analysis, there was a greater similarity of $\mathrm{K}$ between AM, trolox and gallic acid, $\mathrm{AQ}$ and L-ascorbic acid, and ALC and $\beta$-carotene, irrespective of $\mathrm{pH}$. Through Cluster analysis, the greatest $\mathrm{K}$ differentiation was at $\mathrm{pH}$ 2.20. In general, AM showed better antioxidant action (TEAC). AQ and ALC showed the highest phenolic and carotenoids content, respectively. The extraction method influenced the content of bioactive compounds in the pequi extracts and, therefore, their antioxidant capacity.
\end{abstract}

Keywords: Solvent; Bioactive compound; Voltammetric analysis; Electrochemical assay; Differential pulse voltammetry; Principal component analysis.

\section{Resumo}

Foi investigado o efeito do procedimento de extração na capacidade antioxidante de extratos da polpa de pequi: aquoso (AQ), alcoólico (ALC) e acetometílico (AM), obtidos respectivamente pelos solventes água, etanol e metanol seguido de acetona. A ação antioxidante foi expressa pelo coeficiente de capacidade antioxidante (K) obtido pelo teste eletroquímico (DPV) em diferentes valores de $\mathrm{pH}$, e em equivalente ao trolox (TEAC), por DPV (pH 7,15) e ensaios espectrofotométricos ABTS e DPPH. Os teores de carotenoides e fenólicos totais também foram determinados. Por meio das análises de Componentes Principais e Cluster, observou-se maior similaridade de K entre AM, trolox e ácido gálico, AQ e ácido L-ascórbico, e ALC e $\beta$-caroteno, independentemente do pH. Por meio da análise de cluster, a 
maior diferenciação de $\mathrm{K}$ foi em pH 2,20. Em geral, o AM apresentou melhor ação antioxidante (TEAC). AQ e ALC apresentaram os maiores teores de fenólicos e carotenoides, respectivamente. O método de extração influenciou o teor de compostos bioativos dos extratos de pequi e, portanto, sua capacidade antioxidante.

Palavras-chave: Solvente; Composto bioativo; Análise voltamétrica; Ensaio eletroquímico; Voltametria de pulso diferencial; Análise de componente principal.

\section{Resumen}

Se investigó el efecto del procedimiento de extracción sobre la capacidad antioxidante de los extractos de pulpa de pequi: acuoso (AQ), alcohólico (ALC) y acetometilo (AM), obtenidos respectivamente por los disolventes agua, etanol y metanol seguido de acetona. La acción antioxidante se expresó mediante el coeficiente de capacidad antioxidante (K) obtenido por la prueba electroquímica (DPV) a diferentes valores de $\mathrm{pH}$, y en equivalente de trolox (TEAC), por DPV ( $\mathrm{pH} 7,15$ ) y ensayos espectrofotométricos ABTS y DPPH. También se determinaron los contenidos totales de carotenoides y fenólicos. Mediante análisis de Componentes Principales y Cluster, se observó una mayor similitud de K entre AM, trolox y ácido gálico, AQ y ácido L-ascórbico, y ALC y $\beta$-caroteno, independientemente del pH. A través del análisis de Cluster, la mayor diferenciación de K fue a pH 2,20. En general, la AM muestra una mejor acción antioxidante (TEAC). AQ y ALC mostraron el mayor contenido de fenólicos y carotenoides, respectivamente. El método de extracción influyó en el contenido de compuestos bioactivos en los extractos de pequi y, por tanto, en su capacidad antioxidante.

Palabras clave: Disolvente; Compuesto bioactivo; Análisis voltamétrico; Ensayo electroquímico; Voltametría de pulso diferencial; Análisis de componentes principales.

\section{Introduction}

Consumption of fruits and vegetables plays an important role in maintaining health, as they provide appreciable amounts of vitamins, minerals, fibers, carotenoids and phenolic compounds, which help to prevent diseases (Chang, Alasalvar, $\&$ Shahidi, 2016). The health protective effects are most often due to the antioxidant action of bioactive compounds (Sharma, Katoch, Kumar, \& Chatterjee, 2021). Thus, a diet rich in antioxidants contributes to the equilibrium of reactive species, protecting the cells from oxidative stress (Jiang et al., 2019).

Due to its favorable geographic and climatic characteristics, Brazil has a wide variety of native and exotic fruit species, which are not yet widely exploited in the diet (Schiassi, Souza, Lago, Campos, \& Queiroz, 2018). Such fruits include the pequi (Caryocar brasiliense Camb.), native to the Brazilian cerrado, typically cultivated in the southeast, northeast and central regions of the country, and economically relevant for the local population (Leão, Franca, Oliveira, Bastos, \& Coimbra, 2017). Although it is not widespread throughout the country, the fruit has potential for human consumption, both because of its high occurrence, as well as its sensory and nutritional characteristics (Gonçalves, Vilas Boas, de Resende, Machado, \& Vilas Boas, 2011).

In recent years, research has reported on the importance of the pequi in relation to antioxidant capacity, attributed mainly to pulp, due to its composition rich in compounds with antioxidant properties (Ferreira et al., 2021a; Ferreira et al., 2021b; Nascimento, Alves, Silva, \& Naves, 2017; Pinheiro et al., 2018; Ribeiro, Fernandes, Alves, Margareth, \& Naves, 2014).

In vitro antioxidant capacity can be evaluated using different methodologies, including spectrophotometric and electrochemical techniques (Apak, Özyürek, Güçlü, \& Çapanołlu, 2016). The results of the antioxidant action are frequently correlated to the content of bioactive compounds predominant in the food matrices analyzed, such as phenolic compounds and carotenoid content.

Obtaining bioactive compounds from the vegetal matrices is traditionally carried out by extraction and concentration processes (Magalhães, Cardoso, \& Reis, 2018). Organic solvents are the most widely used.

The preparation of the extracts is a critical point in the analyses, since the rates of antioxidant capacity are directly influenced by the efficiency of the extraction process.

Thus, research has sought to determine optimal conditions for extracting bioactive compounds. Factors evaluated 
include: extraction method, extraction solvent type, time and temperature of extraction (Das \& Eun, 2018; Machado, Mello, \& Hubinger, 2013; Makanjuola, 2017). Regarding the pequi, no study has been found that evaluates the effect of the extraction process on the antioxidant potential of extracts, determined by voltammetric techniques.

Therefore, the aim of this study is to evaluate the influence of three solvent-based extraction methods on the antioxidant capacity of pequi pulp extracts, estimated by voltammetric and spectrophotometric assays. The phenolic compounds and total carotenoid content of the extracts were also evaluated.

\section{Methodology}

The present study is classified as applied, quantitative and experimental research (Gil, 2008). Experimental research requires prior knowledge from the researcher and allows for selection and greater control of variables, especially under laboratory conditions (Koche, 2011). In this type of research, as it is a quantitative approach (Pereira, Shitsuka, Parreira, \& Shitsuka, 2018), the data were analyzed using different statistical techniques as detailed in item 2.6. The experiments were carried out in the laboratories of the Department of Food Technology (DTA) and Department of Chemistry (Applied Electroanalytical Group - GEAP) of the Federal University of Viçosa and in the Research and Development Laboratory of the Federal Institute of Espírito Santo campus Venda Nova do Imigrante, Brazil.

\subsection{Reagents and standards}

During the experiments, the following solvents were used: acetone, acetic acid, boric acid, phosphoric acid, ethanol, sodium hydroxide and methanol, purchased from Vetec (Duque de Caxias, RJ, Brazil); sodium carbonate, sodium sulfate and petroleum ether purchased from Dinâmica Química (Diadema, SP, Brazil), Folin-Ciocalteu reagent purchased from Êxodo Científica (Hortolândia, SP, Brazil), 2,2'-azinobis (3-ethylbenzthiazoline-6-sulfonic acid) (ABTS), 2,2-diphenyl-1picrylhydrazyl (DPPH) and potassium persulfate purchased from Sigma-Aldrich Chemical Company (St. Louis, MO, USA).

All reagents used were of analytical grade. The antioxidants standards L-ascorbic acid, gallic acid, $\beta$-carotene and 6-hydroxy2,5,7,8-tetramethylchroman-2-carboxylic acid (Trolox) were purchased from Sigma-Aldrich Chemical Company (St. Louis, MO, USA).

\subsection{Pequi pulp extracts}

Pequi mature fruits (Caryocar brasiliense Camb.) were collected during December 2015 in Santana de Pirapama,

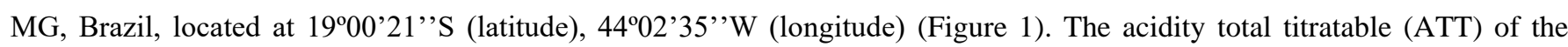
pequi fruits were equal to $0.17 \pm 0.01 \%$ (expressed as citric acid, $\mathrm{m} / \mathrm{m}$ ); total soluble solids content (SST) equal to $6.0 \pm 0.0$ ${ }^{\circ}$ Brix and ratio (SST/ATT) equal to 35.29 .

To obtain the pulp, a fruit pulping machine, model bonina $0.25 \mathrm{df}$ (Itametal/NPC Equipamentos, Itabuna, BA, Brazil) was used. From the pulp, three extracts were prepared, identified as: aqueous extract (AQ), alcoholic extract (ALC) and acetomethyl extract (AM), according to the solvent extractor.

The acetomethyl extract was prepared according to Rufino et al. (2007), using the solvent 50\% (v/v) methanol first, followed by re-extraction with $70 \%(\mathrm{v} / \mathrm{v})$ acetone.

The aqueous and alcoholic extracts were prepared according to Machado et al. (2013), with modifications. Therefore, $20 \mathrm{~g}$ of pequi pulp, previously thawed, was added to distilled water (AQ) or 95\% ethanol (ALC) in the proportion of 1:3 (m/m, pulp: solvent). The mixture was homogenized in an amber flask, using a magnetic stirrer DiagTech DT3110H (São Paulo, SP, Brazil) at $750 \mathrm{rpm}$ for 2 hours at room temperature. The material was then centrifuged at $15,000 \mathrm{rpm}$ for $15 \mathrm{minutes}$ at $25^{\circ} \mathrm{C}$ in 
a Beckman J2-MC centrifuge (Beckman Coulter, Inc., Fullerton, CA, USA) and the supernatant filtered under vacuum on filter paper. The extract was placed in an amber flask and stored at $-18^{\circ} \mathrm{C}$.

Figure 1. Map of the location of harvest of pequi fruits.

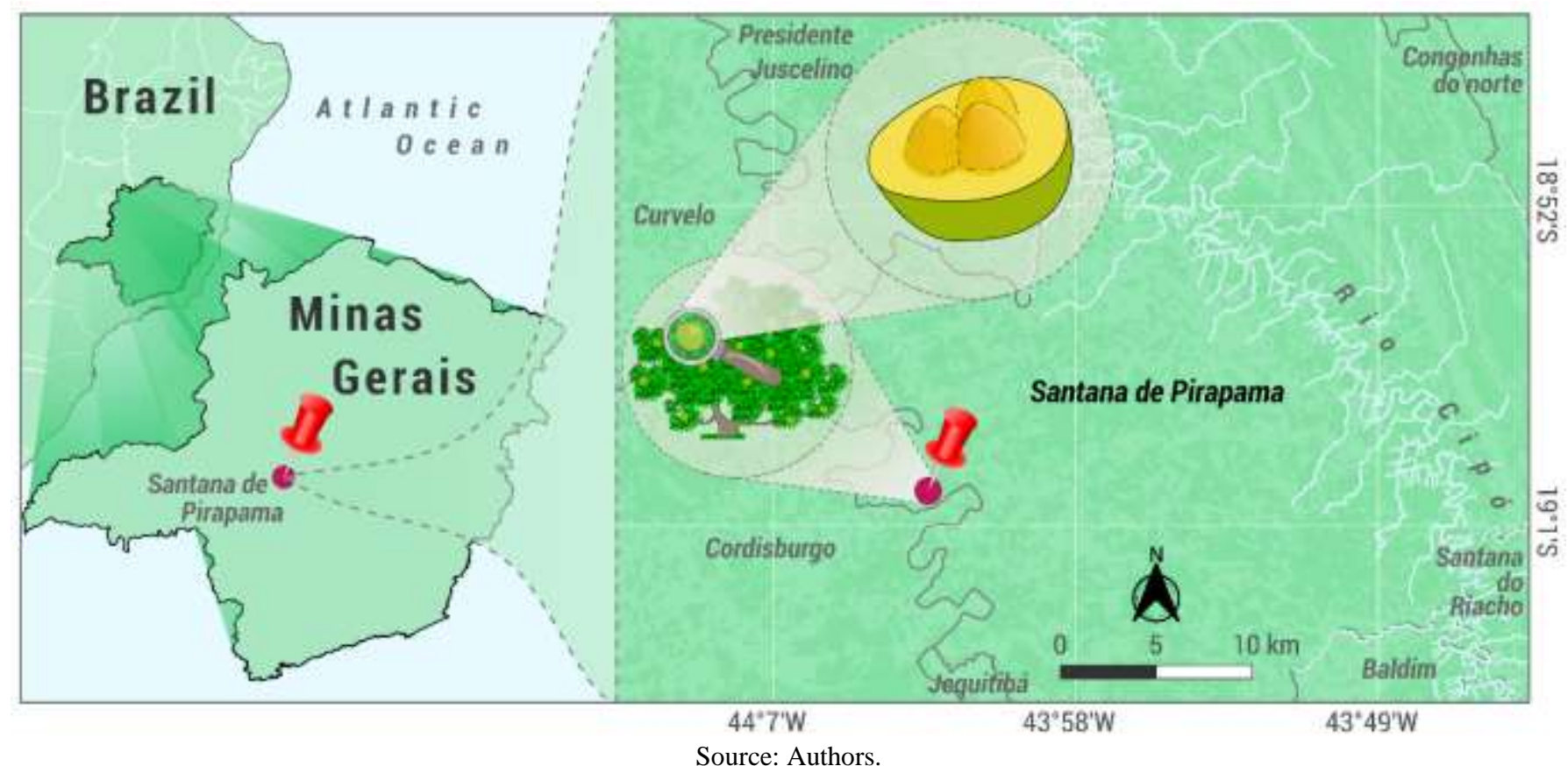

\subsection{Evaluation of antioxidant capacity in vitro}

\subsubsection{Electrochemical assay}

Voltammetric measurements were performed on a potentiostat/galvanostat Autolab Metrohm Pensalab integrated to the GPES 4.9 software (Utrecht, The Netherlands). A three-electrode cell was employed incorporating a gold working electrode with geometric area of $0.196 \mathrm{~cm}^{2}$, a platinum wire auxiliary electrode and an $\mathrm{Ag} \mid \mathrm{AgCl}\left(3.0 \mathrm{~mol} \mathrm{~L} \mathrm{KCl}^{-1} \mathrm{Keference}\right.$ electrode (Metrohm, Herisau, Switzerland). The surface of the working electrode was cleaned by polishing with $0.3 \mu \mathrm{m}$ alumina suspension Buehler (Lake Bluff, IL, USA) in metallographic felt, followed by cleaning with ultrapure water (resistivity $18.2 \mathrm{M} \Omega \cdot \mathrm{cm}$ at $25^{\circ} \mathrm{C}$ ) obtained from Milli-Q deionization system (Millipore, Bedford, MA, USA).

Total antioxidant capacity of the pequi pulp extracts was evaluated based on oxygen electroreduction in 0.1 mol $\mathrm{L}^{-1}$ Britton-Robinson buffer support electrolyte, applying the voltammetric differential pulse technique (DPV), according to Pinheiro et al. (2018). The antioxidant capacity was expressed by the coefficient of antioxidant capacity (K) at $\mathrm{pH} 2.20 ; 4.05$; 7.15 and 10.05 , and by trolox equivalent ( $\mu \mathrm{mol}$ trolox $\mathrm{mL}^{-1}$ pequi extract), based on the intensity values of the cathodic oxygen current obtained at $\mathrm{pH} 7.15$.

The $\mathrm{K}$ values of the three pequi pulp extracts were compared with the antioxidant standards L-ascorbic acid, gallic acid, $\beta$-carotene and trolox (prepared in $95 \%$ ethanol).

\subsubsection{Spectrophotometric assays}

The spectrophotometric methods used to evaluate the antioxidant capacity were based on the DPPH and ABTS assays, described by Brand-Williams, Cuvelier and Berset (1995) and Re et al. (1999), respectively, with modifications described by Pinheiro et al. (2018). 
The measurements were carried out by using a spectrophotometer BEL Photonics UV-M51 (Piracicaba, SP, Brazil), at $515 \mathrm{~nm}(\mathrm{DPPH})$ and $734 \mathrm{~nm}$ (ABTS). Antioxidant capacity was expressed in trolox equivalent $-\mathrm{TEAC}\left(\mu \mathrm{mol}\right.$ trolox mL ${ }^{-1}$ pequi extract), calculated from the trolox analytical curve, prepared with standard solutions ranging between 30 and $600 \mu \mathrm{mol}$ $\mathrm{L}^{-1}$ (DPPH assay) and 10 to $100 \mu \mathrm{mol} \mathrm{L} \mathrm{L}^{-1}$ (ABTS assay).

\subsection{Estimation of total phenolic compounds}

The phenolic content was determined based on the Folin-Ciocalteau assay (Swain \& Hills, 1959), with modifications. $0.25 \mathrm{ml}$ of diluted pequi extract and $2.5 \mathrm{ml}$ of $10 \%$ Folin-Ciocalteau reagent were put in test tubes. The mixture was stirred and allowed to stand for 4 minutes. $2 \mathrm{ml}$ of $7.5 \%$ sodium carbonate solution was added, then it was left to stand in a dark environment at room temperature for 90 minutes. Absorbance values were measured at $760 \mathrm{~nm}$ in an Agilent Technologies Cary 60 UV-Vis spectrophotometer (Santa Clara, CA, USA), previously calibrated with distilled water. Total phenolic content was obtained based on a standard curve of gallic acid, with concentrations between 10 and $120 \mathrm{mg} \mathrm{L}^{-1}$, the results being expressed as gallic acid equivalents $\left(\mu \mathrm{g} \mathrm{GAE} \mathrm{mL}^{-1}\right.$ pequi extract).

\subsection{Determination of total carotenoids}

Total carotenoid content of the pequi extracts was estimated according to the methodology described by RodriguezAmaya (2001), with modifications. $5 \mathrm{ml}$ of extract and $10 \mathrm{ml}$ of petroleum ether were mixed in a separatory funnel, followed by manual stirring and discarding of the aqueous phase. The ether phase (carotenoid extract in petroleum ether) was washed with distilled water four times, discarding the aqueous phase. Carotenoid extract in petroleum ether was filtered on filter paper containing anhydrous sodium sulfate into a $25 \mathrm{~mL}$ flask. The volume was completed with petroleum ether and then absorbance at $450 \mathrm{~nm}$ was read in Agilent Technologies Cary $60 \mathrm{UV}$-Vis spectrophotometer (Santa Clara, CA, USA), previously calibrated with petroleum ether. The analysis was performed in a low light environment throughout. The total carotenoid content was obtained using Equation (1):

$$
C T(\mu g / m L)=\left(A \times V \times 10^{6}\right) /\left(A_{1 c m}^{1 \%} \times v \times 100\right)
$$

where, $C T=$ total carotenoid content, expressed in $\beta$-carotene equivalent ( $\mu$ g carotenoids $\mathrm{mL}^{-1}$ pequi extract); $A=$ absorbance of the solution at $450 \mathrm{~nm} ; V=$ final solution volume $(\mathrm{mL}) ; A_{1 \mathrm{~cm}}^{1 \%}=$ molar absorptivity coefficient of $\beta$-carotene in petroleum ether (2592) and $v=$ volume of pequi extract $(\mathrm{mL})$.

\subsection{Statistical analysis}

Results were expressed as mean \pm standard deviation $(n=3)$. The $K$ values were determined by means of linear regression analysis. To identify factors, components or groupings of compounds, Factorial Analysis according to Principal Components was used. The overall suitability of factor extraction was verified by the Bartlett sphericity test, at 5\% significance. As an aid to Principal Component Analysis (PCA), the Hierarchical Grouping method was applied using Euclidean Distances for the formation of groups, presented as a Dendrogram.

For comparisons between extracts and antioxidant standard compounds, the adhesion test to normal distribution, Kolmogorov-Smirnov, and homogeneity of variances, Levene test, were previously performed, both at 5\% significance. The multiple comparison of extracts and antioxidant patterns was done using variance analysis (ANOVA) and Kruskal-Wallis nonparametric test, at 5\% significance level. The Tukey (parametric) and Mann-Whitney (non-parametric) tests at 5\% significance 
were used to compare means. Pearson correlation was also applied to establish relationship between extracts and antioxidant patterns, as a function of $\mathrm{K}$.

Statistical analyses were performed using SPSS software (Statistical Package for the Social Sciences) for Windows version 20.0.

\section{Results and Discussion}

\subsection{Antioxidant capacity expressed by the coefficient of antioxidant capacity (K): electrochemical test}

From the electroreduction of the oxygen by the voltammetric test, it was possible to observe a decrease in the $\mathrm{O}_{2}$ current with the addition of pequi pulp extracts (aqueous, alcoholic and acetomethyl) and antioxidant standards (L-ascorbic acid, gallic acid, $\beta$-carotene and trolox), making it possible to evaluate the antioxidant capacity of these extracts. The $\mathrm{O}_{2}$ reduction behavior was observed in all studied $\mathrm{pH}$ values $(\mathrm{pH} 2.20,4.05,7.15$ and 10.05). The voltammograms of oxygen electroreduction in Britton-Robinson $0.1 \mathrm{~mol} \mathrm{~L}^{-1}$ buffer, $\mathrm{pH} 4.05$, with the addition of extracts aqueous, alcoholic and acetomethyl, as well as the curves of variation of the current rate in function of the pequi extract volume $\left[\left(I_{p c}-I_{\text {res }}\right) /\left(I_{p 0}-I_{\text {res }}\right)=f(v)\right]$, are shown in the Figure 2. Where $I_{p c}$ is the peak cathodic current of $\mathrm{O}_{2}$, in the presence of pequi extract; $I_{r e s}$ is the peak cathodic current of the deoxygenated supporting electrolyte, $I_{p 0}$ is the initial peak cathodic current of $\mathrm{O}_{2}$ without added extract and $\mathrm{v}$ is the volume of pequi extract.

Figure 3 shows the dispersions between the volume of pequi extract and antioxidant standards and the rate of cathodic oxygen current, by $\mathrm{pH}$. An inverse relationship was noted between the increase in volume and the current rate for all the extracts and compounds studied, confirming what has been previously described.

In Figure 3, we can see the correlation of the current rate between each extract and antioxidant pattern, by $\mathrm{pH}$ of the medium. In this case, correlation refers to the dispersion of points tending to a rising (positive correlation) or decreasing (negative correlation) linear curve. The dispersion of points without forming a linear model represents a correlation that cannot be explained linearly, or non-correlation. Comparing the pequi extracts with the trolox standard antioxidant, it was observed that at $\mathrm{pH} 2.20$, only the current rates of the extracts AQ and ALC showed a positive correlation with trolox. At $\mathrm{pH} 4.05$ and 10.05, a positive correlation trend was observed for all extracts. At $\mathrm{pH} 7.15$, it can be inferred that there was no correlation, since the points did not present a linear trend. 


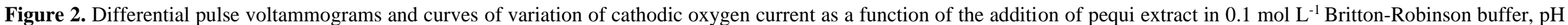
4.05 .
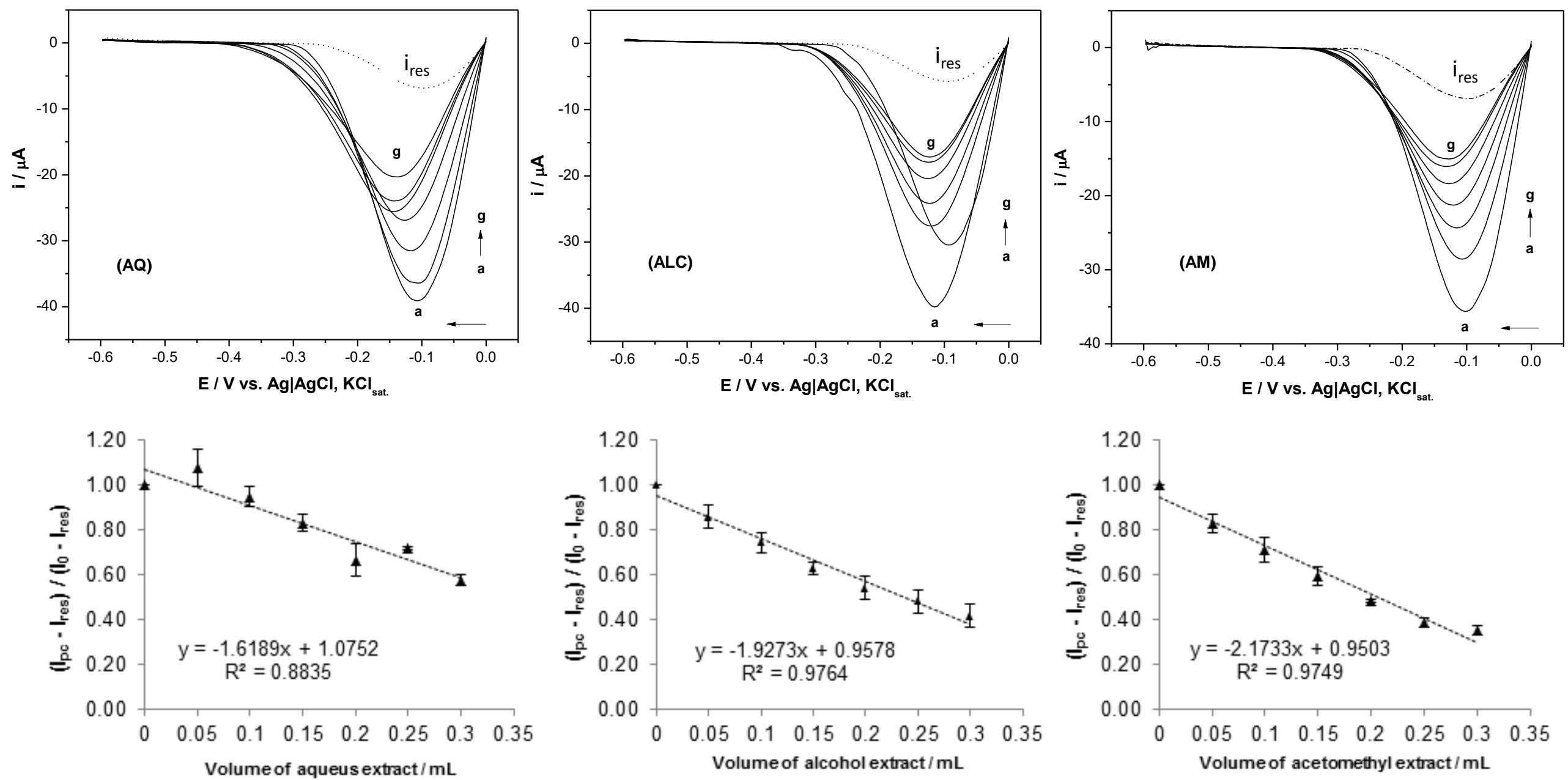

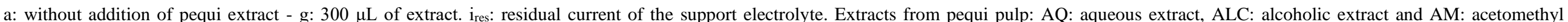
extract. Source: Authors. 
Figure 3. Dispersion between volume of pequi extracts and antioxidant standards and cathodic oxygen current rate.
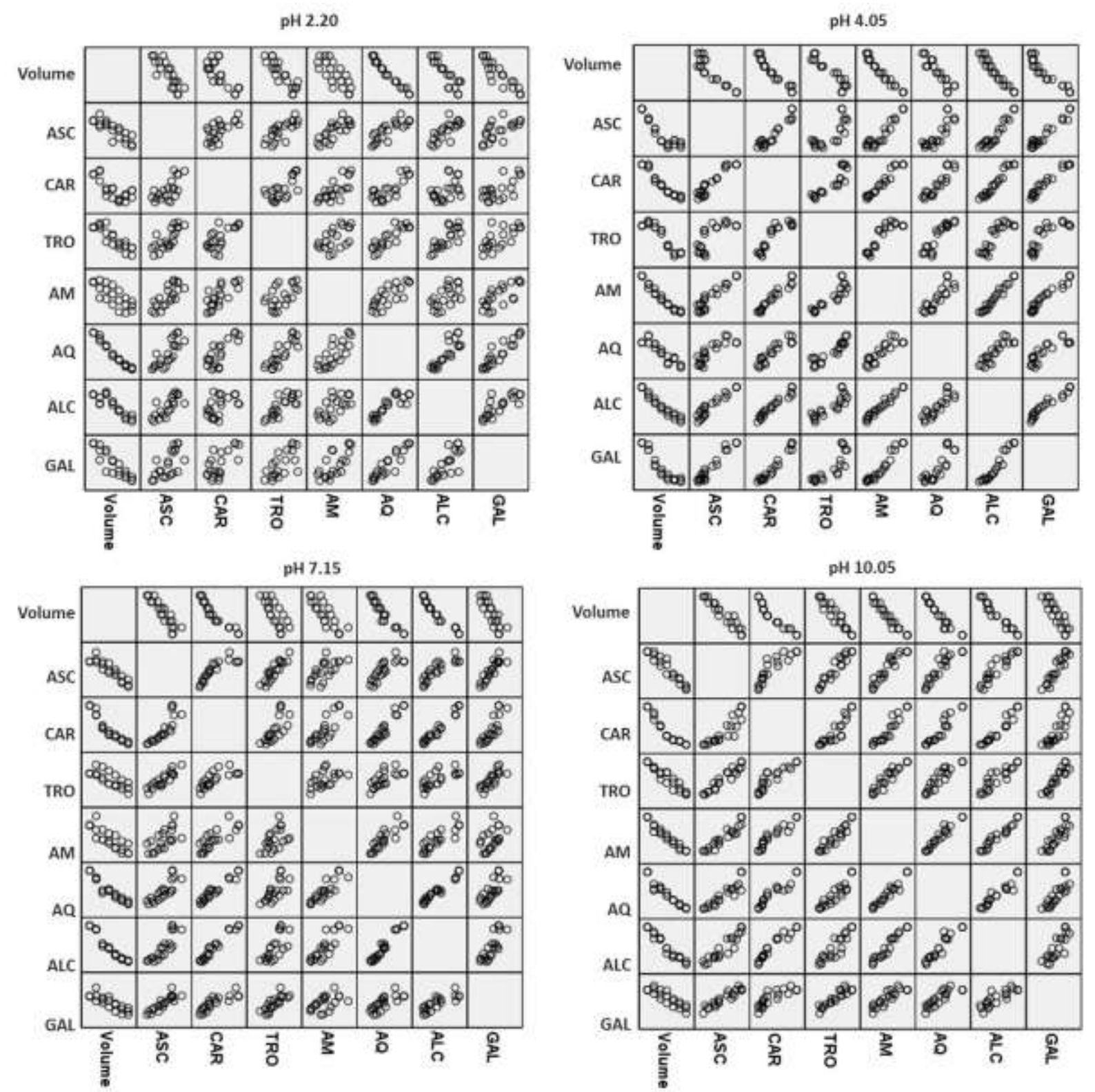

Extracts from pequi pulp: AQ: aqueous extract, ALC: alcoholic extract and AM: acetomethyl extract. ASC: L-ascorbic acid, GAL: gallic acid, CAR: $\beta$-carotene and TRO: trolox. Source: Authors.

The coefficient of antioxidant capacity was obtained from the angular coefficient (in modulus) of the curves described by the regression analysis $\left[\left(I_{p c}-I_{\text {res }}\right) /\left(I_{p 0}-I_{\text {res }}\right)=f(v)\right]$, for each pequi extract and antioxidant standards, at a given pH of the medium. The mean values of $\mathrm{K}$ ( \pm standard deviation) are shown in Table 1. 
Table 1. Coefficient of antioxidant capacity $(\mathrm{K})$ of extracts of pequi pulp and antioxidant standards, at different $\mathrm{pH}$ values

\begin{tabular}{lcccc}
\hline \multirow{2}{*}{ Extracts/Compounds } & \multicolumn{3}{c}{ Coefficient of antioxidant capacity / $\mathbf{~ L}^{-1}$} \\
\cline { 2 - 5 } & $\mathbf{p H ~ 2 . 2 0 ^ { * }}$ & $\mathbf{p H ~ 4 . 0 5 *}$ & $\mathbf{p H ~ 7 . 1 5 ^ { * * }}$ & $\mathbf{p H ~ 1 0 . 0 5 *}^{*}$ \\
\hline AQ & $1.949 \pm 0.023^{\mathrm{a}}$ & $1.619 \pm 0.067^{\mathrm{e}}$ & $1.852 \pm 0.089^{\mathrm{a}}$ & $2.289 \pm 0.105^{\mathrm{a}}$ \\
ALC & $1.333 \pm 0.132^{\mathrm{bc}}$ & $1.927 \pm 0.137^{\mathrm{bcd}}$ & $1.940 \pm 0.034^{\mathrm{a}}$ & $1.897 \pm 0.143^{\mathrm{ab}}$ \\
AM & $1.719 \pm 0.202^{\mathrm{ab}}$ & $2.173 \pm 0.044^{\mathrm{a}}$ & $1.805 \pm 0.234^{\mathrm{a}}$ & $1.704 \pm 0.139^{\mathrm{b}}$ \\
CAR & $1.027 \pm 0.031^{\mathrm{c}}$ & $1.872 \pm 0.020^{\mathrm{cd}}$ & $1.954 \pm 0.096^{\mathrm{a}}$ & $1.985 \pm 0.100^{\mathrm{ab}}$ \\
ASC & $1.577 \pm 0.266^{\mathrm{abc}}$ & $1.846 \pm 0.136^{\mathrm{d}}$ & $1.542 \pm 0.121^{\mathrm{a}}$ & $2.222 \pm 0.172^{\mathrm{a}}$ \\
GAL & $1.826 \pm 0.249^{\mathrm{ab}}$ & $2.074 \pm 0.023^{\mathrm{abc}}$ & $1.523 \pm 0.315^{\mathrm{a}}$ & $1.784 \pm 0.251^{\mathrm{b}}$ \\
TRO & $1.616 \pm 0.292^{\mathrm{ab}}$ & $2.130 \pm 0.034^{\mathrm{ab}}$ & $1.773 \pm 0.378^{\mathrm{a}}$ & $1.587 \pm 0.122^{\mathrm{b}}$ \\
\hline
\end{tabular}

Mean \pm standard deviation $(n=3)$. AQ: aqueous pequi extract; ALC: alcoholic extract; AM: acetomethyl extract; ASC: L-ascorbic acid; GAL: Gallic acid. CAR: $\beta$-carotene and TRO: trolox. ${ }^{*} \mathrm{pH}$ 2.20, 4.05 and 10.05: means followed by different letters, in the same column, differ statistically from each other according to the Tukey test $(\mathrm{p}<0.05)$. ** $\mathrm{pH} 7.15$ : means followed by the same letters do not differ statistically from each other according to the Kruskal-Wallis test ( $p>0.05)$. Source: Authors.

According to Table 1, mean values of $\mathrm{K}$ were between $1.027 \pm 0.031 \mathrm{~mL}^{-1}$ and $2.289 \pm 0.105 \mathrm{~mL}^{-1}$, respectively for $\beta$ carotene $(\mathrm{pH} 2.20)$ and aqueous pequi extract $(\mathrm{pH} 10.05)$. A variation of the coefficient of antioxidant capacity ( $\mathrm{p}<0.05)$ was observed for the extracts and patterns studied, at $\mathrm{pH} 2.20 ; 4.05$ and 10.05 . In relation to $\mathrm{pH} 7.15$, there was no difference (p > 0.05) for the antioxidant action between extracts and compounds.

In order to obtain better grouping of the compounds evaluated in relation to the $\mathrm{K}$ values, Principal Component Analysis (PCA) and Cluster Analysis were performed (Figure 4).

Based on PCA (Figure 4a), three components were defined with $36.6 \%$ of the total variance being shared for the formation of the first component, $31.0 \%$ for the second and $20.7 \%$ for the third. Therefore, the three components allowed an explanation of $88.3 \%$. The acetomethyl extract of pequi and trolox were the compounds that contributed most to the formation of component 1 , the alcoholic extract and the $\beta$-carotene pattern for the formation of component 2 and the antioxidant Lascorbic acid and gallic acid patterns for component 3.

The clusters formed by the PCA can be better distinguished by Cluster analysis. This analysis allowed the formation of two large groups for pequi extracts and antioxidant patterns in relation to $\mathrm{K}$ values (Figure $4 \mathrm{~b}$ ). The first group had more elements, being formed by the extracts of pequi alcoholic and acetomethyl and by the gallic acid, $\beta$-carotene and trolox patterns. The second group was formed only by aqueous pequi extract and L-ascorbic acid. It can be emphasized that two subgroups were formed within the first large group, separating the alcoholic and acetomethyl extracts of pequi. Classification of the extracts into three subgroups was based on the different extraction procedures/extraction solvents to obtain bioactive compounds from the pequi pulp, that is, the chemical composition of the final extracts, which directly reflects on the antioxidant capacity of the extracts evaluated. Therefore, the results confirm that the method used for extraction influences the antioxidant action estimated by the voltammetric protocol applied. 


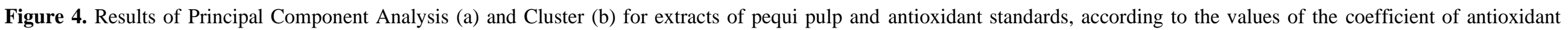
capacity (K), irrespective of $\mathrm{pH}$.
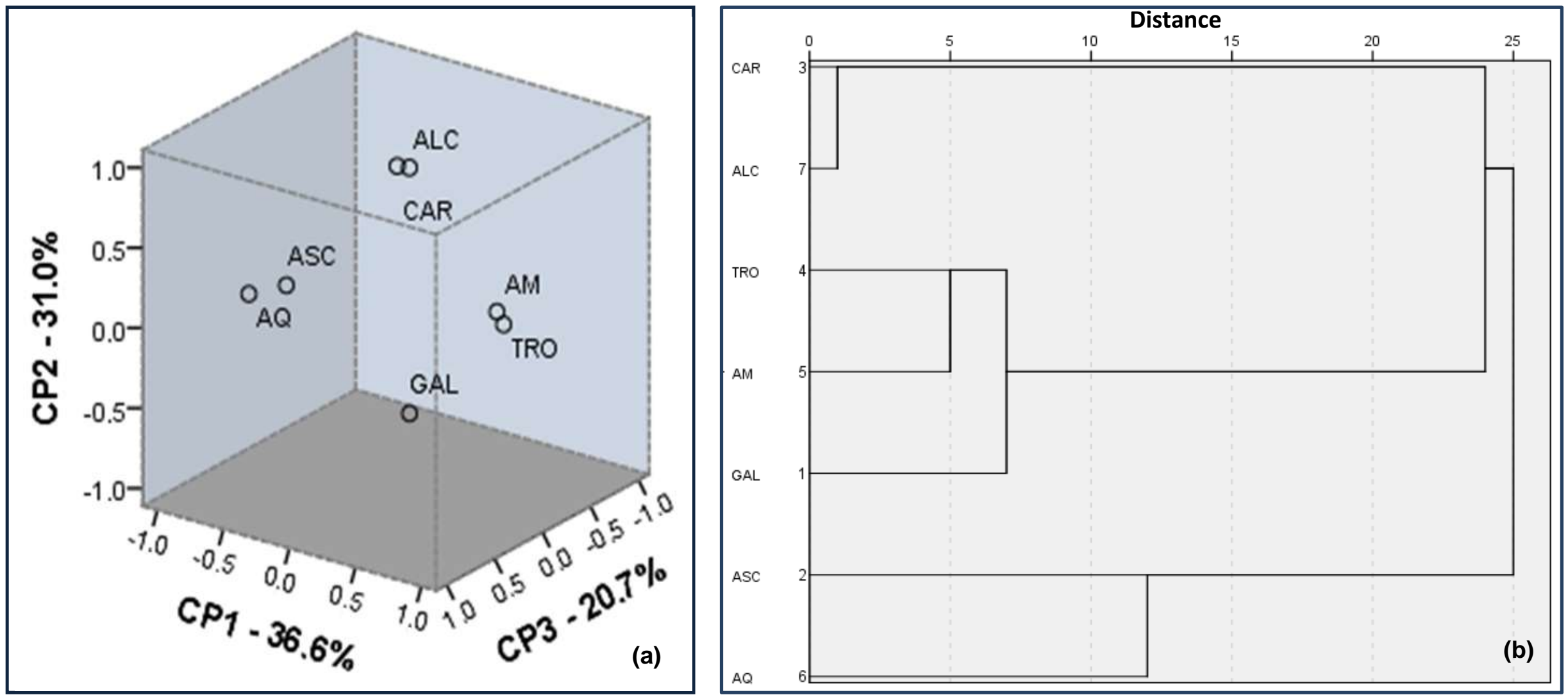

AQ: aqueous pequi extract; ALC: alcoholic extract; AM: acetomethyl extract; ASC: L-ascorbic acid; GAL: gallic acid, CAR: $\beta$-carotene and TRO: trolox. Source: Authors. 
The correlation of the antioxidant capacity, expressed by the mean values of $\mathrm{K}$, between extracts and antioxidant standards, was also evaluated. The results are shown in Table 2.

Table 2. Results of the Pearson correlation between the compounds for the mean values of K, irrespective of $\mathrm{pH}$.

\begin{tabular}{cccccccc}
\hline & \multicolumn{7}{c}{ Correlation } \\
\cline { 2 - 7 } Pequi extracts & AM & AQ & ALC & CAR & ASC & GAL & TRO \\
\hline AM & 1.000 & -0.552 & 0.327 & 0.288 & -0.015 & 0.480 & $0.615^{*}$ \\
AQ & -0.552 & 1.000 & -0.061 & 0.045 & 0.466 & -0.229 & $-0.582^{*}$ \\
ALC & 0.327 & -0.061 & 1.000 & $0.934^{* *}$ & 0.412 & -0.068 & 0.277 \\
\hline
\end{tabular}

*Significant correlation at the 5\% level. **Significant correlation at the 1\% level. AQ: aqueous pequi extract; ALC: alcoholic extract; AM: acetomethyl extract; ASC: L-ascorbic acid; GAL: Gallic acid. CAR: $\beta$-carotene and TRO: trolox. Source: Authors.

By evaluating the significant correlations described in Table 2, it is possible to observe a positive significance between the acetomethyl extract and trolox, and between the alcoholic extract and the $\beta$-carotene standard. These results can be related to the formation of the groups in the Principal Component and Cluster analyses. For the aqueous extract, there was a significant negative correlation between trolox.

To better understand the results obtained by the study of $\mathrm{K}$ values as a function of $\mathrm{pH}$, Cluster analysis was performed (Figure 5).

Figure 5. Dendrogram with the Cluster analysis results for different $\mathrm{pH}$ values as a function of the antioxidant capacity coefficients $(\mathrm{K})$ obtained for the pequi extracts and antioxidant standards

\section{Distance}

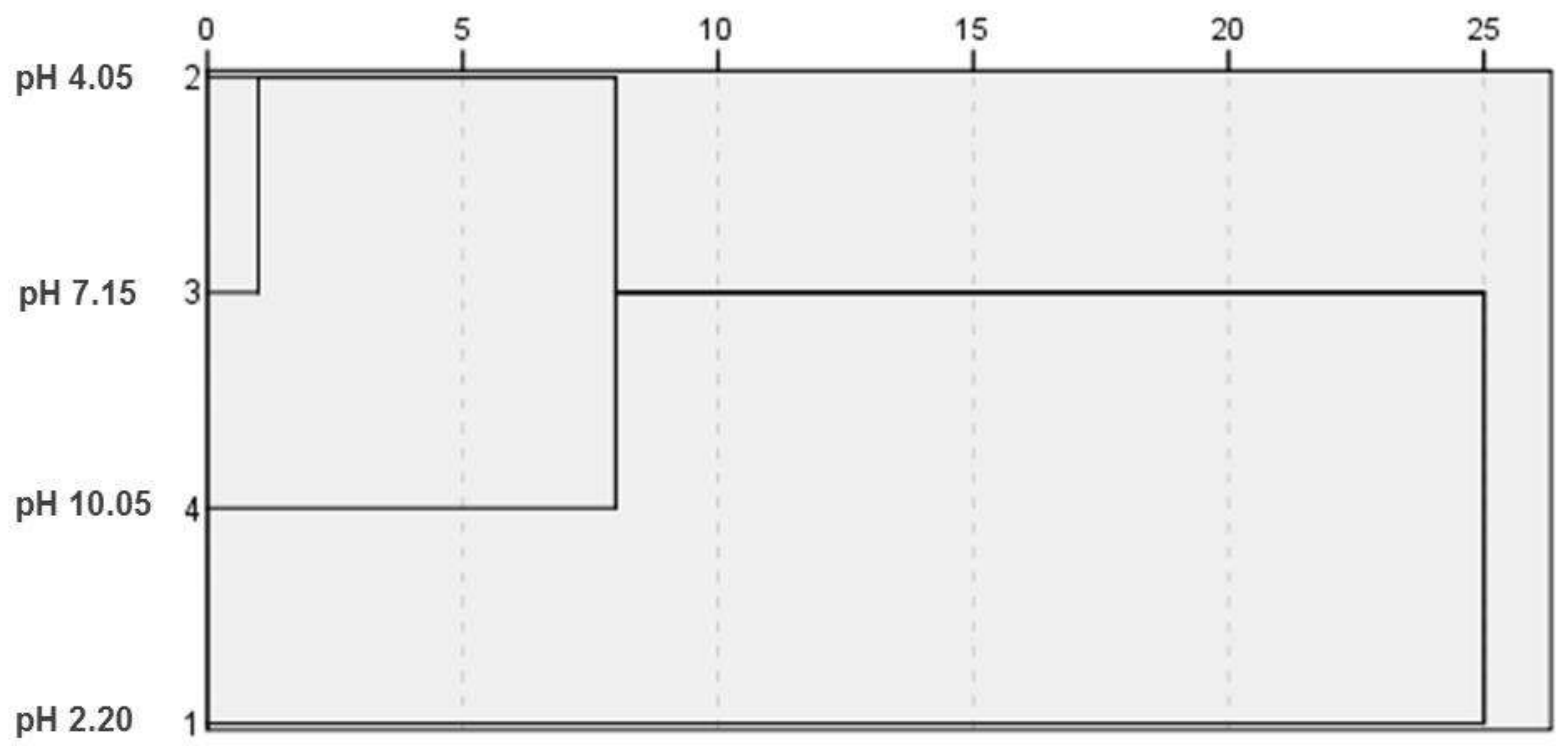

Source: Authors. 
Based on this evaluation it was possible to obtain two large groups, the first being formed by the $\mathrm{pH}$ values 4.05 ; 7.15 and 10.05 and the second at $\mathrm{pH} 2.20$. Two subgroups were formed within the first group, $\mathrm{pH} 4.05$ and $\mathrm{pH} 7.15$ being classified in the same subgroup, according to the similarity of $\mathrm{K}$ values, in relation to the others.

These results reinforce the importance of $\mathrm{pH}$ study to evaluate the antioxidant capacity of food matrices.

Figure 5 shows that the antioxidant action (expressed by the K values) of the extracts and patterns obtained at $\mathrm{pH} 2.20$ was that which most differed in relation to the other $\mathrm{pH}$ studied.

The relationship of $\mathrm{pH}$ to antioxidant capacity occurs by the deprotonation of antioxidant compounds, as a function of their pKa values (Alberto, Russo, Grand, \& Galano, 2013; Altunkaya, Gökmen, \& Skibsted, 2016). According to Lemańska et al. (2001), the antioxidant action increases with deprotonation of the hydroxyl fraction, since the electron donation becomes easier.

\subsection{Antioxidant capacity expressed as trolox equivalent: comparison between DPV, ABTS and DPPH assays}

According to Barros, Andrade, Denadai, Nunes, and Narain (2017), for greater precision and reliability in the presentation of results on the antioxidant action of complex matrices, it is advisable to apply different antioxidant assays, since these differ in relation to the principle and experimental conditions. Likewise, in addition to assessing the influence of the extraction methods on the antioxidant action of pequi extracts, expressed by $\mathrm{K}$, previously described, this study sought to compare the data obtained by the electrochemical DPV assay at pH 7.15 with the ABTS and DPPH spectrophotometric assays. The results were expressed by trolox equivalence ( $\mu \mathrm{mol}$ of trolox $\mathrm{mL}^{-1}$ pequi extract) and are shown in Figure 6 .

Figure 6. Antioxidant capacity of pequi pulp extracts expressed in trolox equivalent, according to the electrochemical DPV assay (pH 7.15) and ABTS and DPPH spectrophotometric assays. Mean \pm standard deviation ( $\mathrm{n}=3)$.

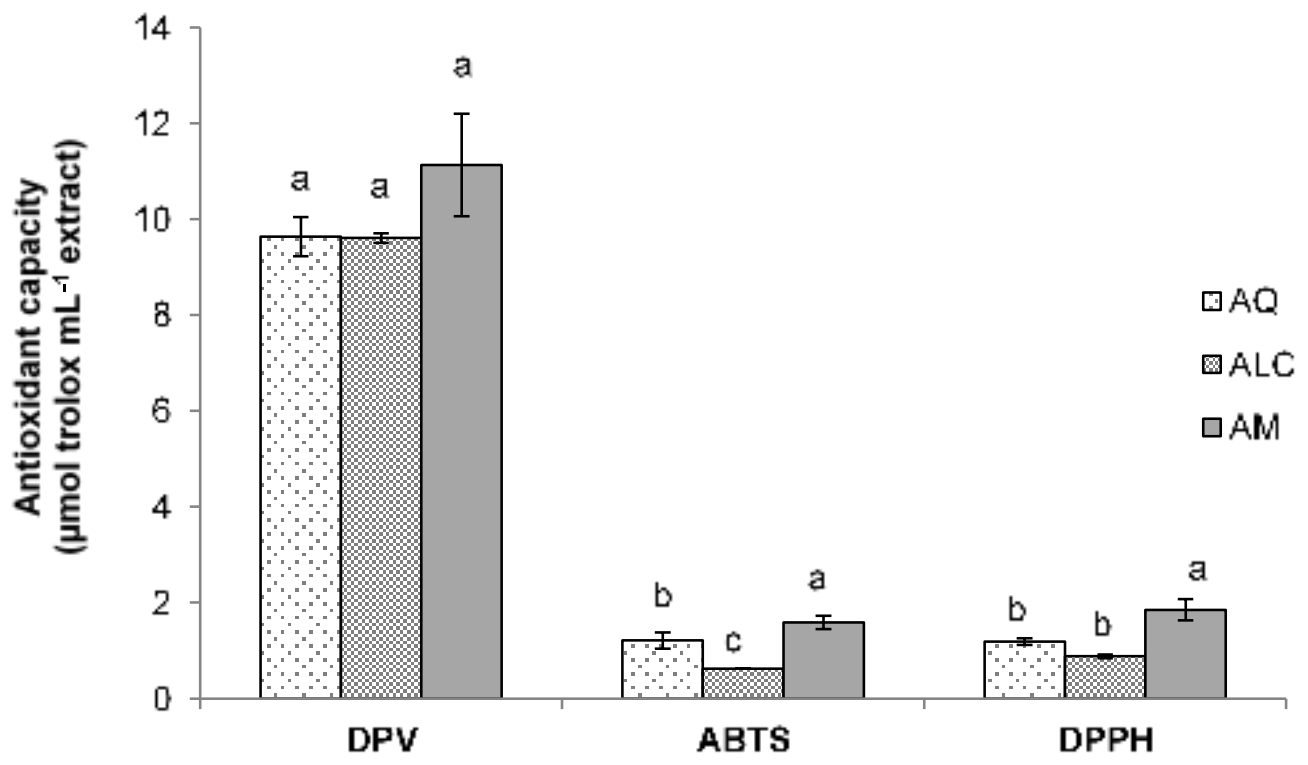

AQ: aqueous pequi extract, ALC: alcoholic extract and AM: acetomethyl extract. DPV: means followed by equal letters do not differ statistically from one another according to the Kruskal-Wallis test $(p>0.05)$. ABTS and DPPH: means followed by different letters, in the same assay, differ statistically from each other according to the Tukey test $(\mathrm{p}<0.05)$. Source: Authors. 
Based on Figure 6, pequi pulp extracts were classified, according to the antioxidant capacity, in the following order: $\mathrm{DPV}: \mathrm{AM}=\mathrm{AQ}=\mathrm{ALC} ; \mathrm{ABTS}: \mathrm{AM}>\mathrm{AQ}>\mathrm{ALC}$, and $\mathrm{DPPH}: \mathrm{AM}>\mathrm{AQ}=\mathrm{ALC}$. In general, greater antioxidant action is observed for the acetomethyl extract.

Variation in the results of antioxidant capacity of plant extracts, evaluated by different methods, was also reported in a study described by Melo et al. (2011).

Comparing average antioxidant capacity between the assays (Figure 6), it can be seen that higher antioxidant action was obtained by the DPV assay for all extracts (AM: $11.13 \pm 1.07 \mu \mathrm{mol}$ trolox $\mathrm{mL}^{-1}$ extract; ALC: $9.61 \pm 0.10 \mu \mathrm{mol}$ trolox mL

${ }^{1}$ extract and AQ: $9.64 \pm 0.41 \mu \mathrm{mol}$ trolox $\mathrm{mL}^{-1}$ extract). According to Pinheiro et al. (2018), the electrochemical technique makes possible the evaluation of the antioxidant action by the synergism of the bioactive compounds, unlike the ABTS and DPPH tests, which are more specific for certain compounds. In addition, the electrochemical technique presents simplicity in the analyzes and high performance (Jiang et al., 2019).

The extraction/solvent extraction method did not influence $(\mathrm{p}>0.05)$ the antioxidant action evaluated by the electrochemical DPV assay, at pH 7.15, as can be observed in Figure 6 (results of antioxidant capacity expressed in trolox equivalent) and in Table 1 (data expressed by the coefficient of antioxidant capacity, K).

In a study conducted by Machado et al. (2013) the aqueous pequi extract showed higher antioxidant action by DPPH $(23.03 \pm 0.36 \%$ inhibition $)$ and FRAP $\left(2.62 \pm 0.007 \mathrm{mM} \mathrm{FeSO}_{4} \mathrm{~mL}^{-1}\right.$ extract $)$ assays than the alcoholic extract $(21.90 \pm 0.54 \%$ inhibition, $2.47 \pm 0.050 \mathrm{mM} \mathrm{FeSO}_{4} \mathrm{~mL}^{-1}$ extract). According to the researchers, these results may have been influenced by the variation of the bioactive compounds present in each extract and by the interaction of each compound with the reaction mechanism involved in the methods applied.

The polarity of the reaction medium inherent in the method used to determine antioxidant capacity may also influence the mechanism of reaction of the antioxidant compounds present in the extracts of the foods evaluated. Thus, variations obtained in the antioxidant action when comparing results of different methods may be due to these factors (Melo et al., 2011).

\subsection{Evaluation of bioactive compounds in the pequi extracts: phenolics and total carotenoids}

The effect of the different extraction procedures for obtaining the pequi extracts on total phenolics and carotenoid content was evaluated. The comparison of means was evaluated by applying the Mann-Whitney test (non-parametric), at 5\% significance level. The aqueous extract had the highest content of phenolic compounds $\left(286.33 \pm 0.74 \mu \mathrm{g} \mathrm{GAE} \mathrm{mL}{ }^{-1}\right.$ extract $)$, followed by the extracts acetomethyl $\left(249.09 \pm 4.26 \mu \mathrm{g} \mathrm{GAE} \mathrm{mL}^{-1}\right.$ extract$)$ and alcoholic $\left(185.17 \pm 10.67 \mu \mathrm{g} \mathrm{GAE}^{-1}\right.$ extract).

Total carotenoid content was calculated as follows: ALC $\left(3.10 \pm 0.39 \mu \mathrm{g}\right.$ carotenoid $\mathrm{mL}^{-1}$ extract $)>\operatorname{AM}(1.37 \pm 0.30$ $\mu \mathrm{g}$ carotenoid $\mathrm{mL}^{-1}$ extract $)>\mathrm{AQ}\left(0.14 \pm 0.01 \mu \mathrm{g}\right.$ carotenoid $\mathrm{mL}^{-1}$ extract $)$.

Therefore, it was observed that in this study the extraction/solvent extraction process promoted a difference $(\mathrm{p}<0.05)$ in the carotenoid and phenolic compound content of the extracts evaluated.

Machado et al. (2013) also found higher content of phenolic compounds in the pequi aqueous extract $(213.70 \pm 1.44$ $\mu \mathrm{g}$ GAE $\mathrm{mL}^{-1}$ extract) than in the alcoholic $\left(138.99 \pm 10.05 \mu \mathrm{g}\right.$ GAE $\mathrm{mL}^{-1}$ extract), and higher carotenoid content in the alcoholic extract $\left(4.42 \pm 0.15 \mu \mathrm{g} \beta\right.$-carotene $\mathrm{mL}^{-1}$ extract $)$ than in the aqueous $\left(2.55 \pm 0.07 \mu \mathrm{g} \beta\right.$-carotene $\mathrm{mL}^{-1}$ extract $)$.

Barros et al. (2017) described that the aqueous extraction system was more efficient than methanolic for phenolic acids (caffeic acid, gallic acid, $p$-coumaric acid, etc.) evaluated in extracts of achachairu, araçá-boi and bacaba fruit residues.

Monteiro, Silva, Martins, Barin and Rosa (2015) verified the effect of the type of solvent and the extraction method on the phenolic content and antioxidant capacity in pequi peel extracts, with the $80 \%$ hydroethanolic extract obtained by 
agitation that which presented the highest content of polyphenols compared to the $80 \%$ hydroethanolic extracts obtained by microwave and aqueous obtained by both methods.

Melo et al. (2011) found better efficiency of extraction of phenolic compounds in ethanolic extracts of agroindustrial residues of grape and guava than in aqueous extracts

In view of the observations described, it can be inferred that there is no specific solvent or extraction procedure to obtain phenolic compounds and carotenoids simultaneously in a complex medium of vegetable origin. Generally, phenolic compounds tend to be polar, therefore better extracted in more polar solvents (Thouri et al., 2017). Carotenoids, specifically carotene, are lipophilic and are soluble in apolar solvents.

Likewise, solvent mixtures can promote improvement of the extraction process based on the use of their properties together (Wijngaard, Hossain, Rai, \& Brunton, 2012).

Methanol and ethanol can be used as co-solvents to increase the solubility of specific phenolic compounds and the selectivity of the extraction (Cassano, De Luca, Conidi, \& Drioli, 2017).

In general, acetone and hexane are used to extract xanthophyll (polar carotenoid) and carotene (non-polar carotenoid), respectively. On the other hand, a mixture of acetone, ethanol and hexane can be used for simultaneous extraction of polar and nonpolar carotenoids. In addition, the miscible properties of acetone and ethanol in water help in the efficient extraction of carotenoids in wet food matrices (Saini \& Keum, 2018).

\section{Conclusion}

The results of this study have shown that extraction/solvent extractor procedures influenced the antioxidant action of pequi pulp extracts, expressed by the coefficient of antioxidant capacity (K), allowing the classification of these extracts in different groups, according to the similarity to the antioxidant patterns studied.

In general, higher antioxidant action (expressed as trolox equivalent) was obtained by the acetomethyl extract. The results obtained by the electrochemical DPV assay presented higher antioxidant capacity than the ABTS and DPPH assays for all the extracts.

Based on these results, it is important to study the extraction/extraction solvent methods for bioactive compounds to determine the antioxidant capacity of food matrices.

As future research, it is recommended to evaluate the antioxidant capacity of pequi pulp extracts from fruits from different regions and different degree of maturation.

\section{Acknowledgments}

The authors thank the Brazilian agencies Conselho Nacional de Desenvolvimento Científico e Tecnológico (Grants No. 440382/2014-9) and Fundação de Amparo à Pesquisa do Estado de Minas Gerais (Grants No. CAG-APQ 01224-14).

\section{References}

Alberto, M. E., Russo, N., Grand, A., \& Galano, A. (2013). A physicochemical examination of the free radical scavenging activity of Trolox: mechanism, kinetics and influence of the environment. Physical Chemistry Chemical Physics, 15(July 2015), 4642-4650. https://doi.org/10.1039/c3cp43319f

Altunkaya, A., Gökmen, V., \& Skibsted, L. H. (2016). pH dependent antioxidant activity of lettuce ( $L$. sativa) and synergism with added phenolic antioxidants. Food Chemistry, 190, 25-32. https://doi.org/10.1016/j.foodchem.2015.05.069

Apak, R., Özyürek, M., Güçlü, K., \& Çapanołlu, E. (2016). Antioxidant activity/capacity measurement. 1. Classification, physicochemical principles, mechanisms, and electron transfer (ET)-based assays. Journal of Agricultural and Food Chemistry, 64(5), 997-1027. https://doi.org/10.1021/acs.jafc.5b04739

Barros, R. G. C., Andrade, J. K. S., Denadai, M., Nunes, M. L., \& Narain, N. (2017). Evaluation of bioactive compounds potential and antioxidant activity in some Brazilian exotic fruit residues. Food Research International, 102(July), 84-92. https://doi.org/10.1016/j.foodres.2017.09.082 
Brand-Williams, W., Cuvelier, M. E., \& Berset, C. (1995). Use of a free radical method to evaluate antioxidant activity. LWT - Food Science and Technology, 28(1), 25-30. https://doi.org/10.1016/S0023-6438(95)80008-5

Cassano, A., De Luca, G., Conidi, C., \& Drioli, E. (2017). Effect of polyphenols-membrane interactions on the performance of membrane-based processes. A review. Coordination Chemistry Reviews, 351, 45-75. https://doi.org/10.1016/j.ccr.2017.06.013

Chang, S. K., Alasalvar, C., \& Shahidi, F. (2016). Review of dried fruits: Phytochemicals, antioxidant efficacies, and health benefits. Journal of Functional Foods, 21, 113-132. https://doi.org/10.1016/j.jff.2015.11.034

Das, P. R., \& Eun, J. B. (2018). A comparative study of ultra-sonication and agitation extraction techniques on bioactive metabolites of green tea extract. Food Chemistry, 253(July 2017), 22-29. https://doi.org/10.1016/j.foodchem.2018.01.080

Ferreira, L. R., Fontes, E. A. F., Marinho, L. M. G., Barros, F. A. R., Stringheta, P. C., Ramos, A. M. (2021a). Elaboration, characterization and color stability of an isotonic beverage based on whey permeate with carotenoid powder from pequi. Research, Society and Development, 10(8), e41810817233. https://doi.org/10.33448/rsd-v10i8.17233

Ferreira, P. R., Pinheiro, F. A., Duarte, M. S., Silva, W., Reis, N. R., Marques, D. B. D., Bastos, D. S. S., Fontes, E. A. F. (2021b). Effect of jaboticaba and pequi extracts on gene expression of antioxidant enzymes in C2C12 mouse muscle cells. Research, Society and Development, 10(10), e375101018864. https://doi.org/10.33448/rsd-v10i10.18864

Gil, A. C. (2008). Métodos e técnicas de pesquisa social. (6a ed.), Atlas.

Gonçalves, G. A. S., Vilas Boas, E. V. B., de Resende, J. V., Machado, A. L., \& Vilas Boas, B. M. (2011). Qualidade dos frutos do pequizeiro submetidos a diferentes tempos de cozimento. Ciência e Agrotecnologia, 35(2), 377-385. https://doi.org/10.1590/S1413-70542011000200020

Jiang, X., Liu, X., Wu, T., Li, L., Zhang, R., \& Lu, X. (2019). Metal-organic framework derived carbon-based sensor for monitoring of the oxidative stress of living cell and assessment of antioxidant activity of food extracts. Talanta, 194, 591-597. https://doi.org/10.1016/j.talanta.2018.10.093

Köche, J. C. (2011). Fundamentos de metodologia científica: teoria da ciência e iniciação à pesquisa. Vozes.

Leão, D. P., Franca, A. S., Oliveira, L. S., Bastos, R., \& Coimbra, M. A. (2017). Physicochemical characterization, antioxidant capacity, total phenolic and proanthocyanidin content of flours prepared from pequi (Caryocar brasilense Camb.) fruit by-products. Food Chemistry, 225, 146-153. https://doi.org/10.1016/j.foodchem.2017.01.027

Lemańska, K., Szymusiak, H., Tyrakowska, B., Zieliński, R., Soffers, A. E., \& Rietjens, I. M. (2001). The influence of pH on antioxidant properties and the mechanism of antioxidant action of hydroxyflavones. Free Radical Biology and Medicine, 31 (7), 869-81. https://doi.org/10.1016/S0891-5849(01)00638-4

Machado, M. T. C., Mello, B. C. B. S., \& Hubinger, M. D. (2013). Study of alcoholic and aqueous extraction of pequi (Caryocar brasiliense Camb.) natural antioxidants and extracts concentration by nanofiltration. Journal of Food Engineering, 117(4), 450-457. https://doi.org/10.1016/j.jfoodeng.2012.12.007

Magalhães, F. S., Cardoso, V. L., \& Reis, M. H. M. (2018). Sequential process with bioadsorbents and microfiltration for clarification of pequi (Caryocar brasiliense Camb.) fruit extract. Food and Bioproducts Processing, 108, 105-116. https://doi.org/10.1016/j.fbp.2018.02.003

Makanjuola, S. A. (2017). Influence of particle size and extraction solvent on antioxidant properties of extracts of tea, ginger, and tea-ginger blend. Food Science and Nutrition, 5(6), 1179-1185. https://doi.org/10.1002/fsn3.509

Melo, P. S., Bergamaschi, K. B., Tiveron, A. P., Massarioli, A. P., Oldoni, T. L. C., Zanus, M. C., Pereira, G. E., \& Alencar, S. M. (2011). Phenolic composition and antioxidant activity of agroindustrial residues. Ciência Rural, 41(6), 1088-1093.

Monteiro, S. S., Silva, R. R., Martins, S. C., Barin, J. S., \& Rosa, C. S. (2015). Phenolic compounds and antioxidant activity of extracts of pequi peel (Caryocar brasiliense Camb.). International Food Research Journal, 22(5), 1985-1992.

Nascimento, N. R. R., Alves, A. M., Silva, M. R., \& Naves, M. M. V. (2017). Antioxidant capacity of pequi (Caryocar brasiliense Camb.) pulp is preserved by freeze-drying and light-resistant packaging. Revista Brasileira de Fruticultura, 39(1), 1-7. https://doi.org/10.1590/0100-29452017150

Pereira, A. S., Shitsuka, D. M., Parreira, F. J., \& Shitsuka, R. (2018). Metodologia da pesquisa científica. UFSM.

Pinheiro, F. A., Okumura, L. L., Silva, A. F. S., Silva, J. G., Ferreira, L. R., Barcellos, E. S., \& Fontes, E. A. F. (2018). Applicability of a voltammetric assay based on the electroreduction of oxygen to evaluate the antioxidant capacity of pequi (Caryocar brasiliense Camb.) pulp. Journal of the Brazilian Chemical Society, 29(8), 1653-1662. https://doi.org/10.21577/0103-5053.20180038

Re, R., Pellegrini, N., Proteggente, A., Pannala, A., Yang, M., \& Rice-Evans, C. (1999). Antioxidant Activity Applying an Improved Abts Radical Cation Decolorization Assay. Free Radical Biology and Medicine, 26(9), 1231-1237. https://doi.org/10.1016/S0891-5849(98)00315-3

Ribeiro, D. M., Fernandes, D. C., Alves, A. M., Margareth, M., \& Naves, V. (2014). Carotenoids are related to the colour and lipid content of the pequi (Caryocar brasiliense Camb.) pulp from the Brazilian Savanna. Food Science and Technology, 34(3), 507-512.

Rodriguez-Amaya, D.B., 2001. A guide to carotenoid analysis in foods. ILST Press.

Rufino, M. S. M., Alves, R. E., Brito, E. S., Morais, S. M., Sampaio, C. G., Pérez-Jiménez, J., Saura-Calixto, F. D. (2007). Metodologia científica: determinação da atividade antioxidante total em frutas pela captura do radical livre ABTS ${ }^{+}$. Comunicado Técnico - EMBRAPA, 128, 1. http://www.cnpat.embrapa.br/cnpat/down/index.php?pub/Cot_128.pdf.

Saini, R. K., \& Keum, Y. (2018). Carotenoid extraction methods: A review of recent developments. Food Chemistry, 240 (April 2017), 90-103. https://doi.org/10.1016/j.foodchem.2017.07.099 
Research, Society and Development, v. 10, n. 12, e498101220663, 2021

(CC BY 4.0) | ISSN 2525-3409 | DOI: http://dx.doi.org/10.33448/rsd-v10i12.20663

Schiassi, M. C. E. V., Souza, V. R., Lago, A. M. T., Campos, L. G., \& Queiroz, F. (2018). Fruits from the Brazilian Cerrado region: Physico-chemical characterization, bioactive compounds, antioxidant activities, and sensory evaluation. Food Chemistry, 245(June 2017), 305-311. https://doi.org/10.1016/j.foodchem.2017.10.104

Sharma, S., Katoch, V., Kumar, S. \& Chatterjee, S. (2021). Functional relationship of vegetable colors and bioactive compounds: Implications in human health. Journal of Nutritional Biochemistry, 92, 108615. https://doi.org/10.1016/j.jnutbio.2021.108615

Statistical Package for the Social Sciences, version 20.0. Chicago: SPSS Inc.

Swain, T., \& Hills, W. E. (1959). The phenolic constituents of Prunus domestica. I.-The quantitative analysis of phenolic constituents. Journal of the Science of Food and Agriculture, 10(1), 63-68. https://doi.org/10.1002/jsfa.2740100110

Thouri, A., Chahdoura, H., Arem, A. El, Hichri, A. O., Hassin, R. Ben, \& Achour, L. (2017). Effect of solvents extraction on phytochemical components and biological activities of Tunisian date seeds (var. Korkobbi and Arechti ). BMC Complementary and Alternative Medicine, 17(248), 1-10. https://doi.org/10.1186/s12906-017-1751-y

Wijngaard, H., Hossain, M. B., Rai, D. K., \& Brunton, N. (2012). Techniques to extract bioactive compounds from food by-products of plant origin. Food Research International, 46(2), 505-513. https://doi.org/10.1016/j.foodres.2011.09.027 